УдК: 398.4(477.85/.87(091) «189/191»

DOI: $10.26661 / \mathrm{zhv}-2019-1-53-32$

\title{
Domestic Spirits in The System of Lower Hutsul
}

\author{
V. P. Ivanchuk \\ Vasyl Stefanyk Precarpation National University \\ vasylivanchuk994@gmail.com
}

Key words: lower mythology, domestic spirits, goblin-ancestor, goblin-nurse child, goblin-animal, Hutzul.
In this article an attempt, based on ethnographical descriptions from the end of the 19th century till the beginning of the 20th century and also the author's modern field materials, is made to follow the peculiarities of Hutzul imagination about home spirits/goblins. In general, among the specified mythological characters we outstand goblin-ancestor (spirit-guardian), goblin-nurse child (spirit-enricher) and goblin- animal. We follow manic genesis of the spirit-guardian as a creator character in the result of fulfilling transitional burial ritual of the genus' ancestor. At the same time, we research ritual customary imitational actions directed at the creation of the spiritenricher (purchase, hatching out of an abnormal egg, coins, inheritance and etc). Characters' functional abilities (guardianship over domestic households, provision of monetary welfare, presenting talents) external -visual (anthropomorphic/ zoomorphic features) and everyday characteristics (food, accommodation, habits) are analyzed in detail. The connection between the goblin and the violent death of the spirit's owner is found. This is correlated with the identification and perception of the spirit-enricher as «dark magic» or devil.

A special attention is paid to the analyses of zoomorphic hypostases of Hutzul domestic spirits (weasel, serpent/eels). Connection between the listed mythical characters and domestic households, namely their guardian functions over the cattle is analyzed. It is also found that the serpent is able to influence imitationally the bad weather, chase away clouds, prevent hail. These abilities in their turn show their connection to the dark dead (prematurely dead, people who committed suicide and drowned, wizards and witches). We also paid attention to syncretic properties of goblin-ancestor, goblin-nurse child and goblin-animal as well. Their ambivalent properties referring to their master are also described here. This paper defines common and distinct properties of Hutzul domestic spirits with their corresponding creatures Ukrainian, Russian, Polish, Lithuanian, Checks, Serbian and Bulgarian lower mythology.

\section{Домашні духи у системі нижчої гуцульської міфології}

\author{
В. П. Іванчук \\ Прикарпатський національний університет ім. В. Стефаника
}

Ключові слова: нижча міфологія, домашні духи, домовик-предок, домовик-вихованець, домовик-тварина, гуцули.
В даній статті здійснено спробу на основі етнографічних описів кінця XIX - початку XX століття, а також сучасних авторських польових матеріалів простежити специфіку гуцульських уявлень про домашніх духів/домовиків. Загалом серед вказаних міфологічних персонажів виокремлено домовика-предка («дух-опікун»), домовика-вихованця («дух-збагачувач») та домовика-тварину. Детально проаналізовано ґенезу, функціональні можливості (покровительство над домашнім господарством, забезпечення грошового достатку, надання таланту), зовнішньо-візуальні (антропоморфні/зооморфні риси) та побутово-повсякденні характеристики (їжа, місце постійного проживання, звички) образів. 
Topicality of the subject. Mythological demonical belief is one of the indispensable parts of any ethnical communal culture and in particular of Hutzul culture. In its turn lower mythology, with belief in demonical creatures of earthly origin, is a structural component of mythological belief. In general, among characters of Hutzul lower mythological tradition one can find: the dead, vampires, suicide people, dead unbaptized babies, field and forest spirits. One of the most important listed characters is a domestic spirit as a demonical creature of folk syncretic outlook. In general, up until today Hutzul domestic spirits are explored in tiny fragments, consequently there is a scientific need of this particular scientific research.

The aim of the article is to research domestic spirits as characters of lower Hutzul mythology. The set goal means solving the following tasks:

- Analyze historical-graphical foundation of resources' problem;

- Define types, find the genesis, functional abilities and external visual characteristics of Hutsul domestic spirits.

The analyses of the latest scientific researches. Partial elements of Hutzul lower mythology were depicted in ethnographical descriptions of Ukrainian and also foreign ethnographers of the late 19th - first half of the 20th centuries, namely: S. Vytvytskyi [1], A. Onyshchuk [2], V. Hnatiuk $[3 ; 4 ; 5]$, V. Shuhevych $[6 ; 7]$, I. Franko [8], P. Shekeryk-Donykiv [9], F. Keindl [10] 0. Kolberg [11] and L. Veigel [12]. Among contemporary field trips during which domestic spirits of the system of lower Ukrainian mythology were researched, one should emphasize on works of 0. Poritska [13] I. Chekhovskyi [14], N. Khobzei [15], I. Buiskyi [16], V. Halaichuk [17; 18], N. Levkovych [19] and N. Voitovych [20]. Mentioned earlier researchers only briefly look through the Hutsul belief in demonical spirits not applying systematical analyses of the given demonical characters.

Main material presentation. Mythological characters, which are genetically connected with the dead relatives in Hutzul lower mythology, are domestic spirits among which we can emphasize goblin-ancestor (spirit-guardian), goblin-nurse child (spirit-enricher) and goblin-animal. In general, all three types of spirits differ in their origin and functional abilities, and in some cases come across as syncretic demonical characters.

Goblin-ancestor is connected in his origin with souls of genus' ancestors, with the spotless dead, who died their own death, passed through the complete burial memorial ritual and acquired the status of the spirit-guardian. Thus, with the aim to transition the dead into the status of goblin spirit-guardian, during the tanathological rituals Hutzuls put the body of a dying person on the «bench» in the back corner of a room [5, p. 261]. This custom is conditioned by understanding of redeeming as a goblin's place of residence. This ritual is overall Slavonic and can be found in the context of calendar customs [21, p. 152]. Also in the Hutzul area there used to be a ban to bring outside the person who is seriously ill because this way the goblin would not stay inside and all the household might follow the dead $[5$, p. 261]. To save and keep the spirit-guardian in the house, a corpse is kept in a room for some time and there is a ritual to lock the door as soon as the body is carried out [22, ark. 2]. These customs testify to the attempt to transition the soul of the dead into the status of the spirit guardian. The notion of blood connection between the domestic spirit-guardians with the dead ancestor is existent in Poland as well (dziady) [23, p. 44]. In Russian grandpa-goblin is the first dead out of people, who settled in the house, the spirit-guardian, the twin of any family member alive [24, p. 135-136]. It should be emphasized that neither in ethnographical descriptions of the previous century, nor in contemporary field materials we did not manage to find information that directly pointed to the genesis of Hutzul domestic spirit from the dark dead. At the same time the goblin-ancestor does not have its own name in Hutzul mythological tradition.

Instead the analyses of the material, taken from the ethnographical descriptions of the previous century and also received from up-to-date field trips, testifies that in the Hutzul lower mythology there happened syncretic combination of the two mythical characters - the spirit-ancestor and the goblin-enricher. Afterwards both domestic spirits got common names and were connected functionally. Ukrainian researcher V. Halaichuk also points to that, indicating that information about a «hideout» (spirit-enricher) and the goblin (spirit-guardian) are identical. The imagination about the goblin-nurse child mostly exists in the Carpathians while belief in the goblin-ancestor is more peculiar to the rest of the Ukrainian territory [25, p. 57].

In Hutzul lower mythology as well as in corresponding believes of the population in Ukrainian Carpathians the character of the spirit-enricher dominates among the domestic spirits [20, p. 29]. On the Hutzul territory this demonical character is known as «goblin-servant» (v. Iasenia; v. Zelena); «hideout» (v. Zalena; t. Kolomyia); «devil» (v. Roztoky; v. Zelene); «he» (v. Zelena); «inclusion» 
(v. Holovy); «antypko» (v. Roztoky); «satan» (v. Kosmach); «shcheznyk» (somebody who disappears); the goblin (v. Holovy); «boy» (v. Samakova) $[2$, p. $74 ; 4$, p. $162 ; 26$, ark. $4 ;$ p.74; 4, p. $2 ; 27$, p. $5 ; 28$, p. 252-253]. In contemporary descriptions we found another synonym of the hideout «devil, goblin» (v. Zelena) [15, p. 102]. Characteristically, most of the names are identified with the dark magic or devil. Accoding to N. Lenkovych the perception of the goblin as the dark magic is formed on the territory of Kyiv-Rus after the adoption of Christianity [19, p. 116]. I. Buiskyi also agrees with the statement and points out that it was the Church that turned home spirits-ancestors into devils and demons, giving them the status of the dark magic that contradicts the God's pure power [29, p. 77].

If the goblin ancestor could be received as a result of conducting transitional tanatological rituals, the spirit-enricher in the Hutzul imagination could be bought or brought up. Thus, up until today on the Hutzul territories there are stories, telling that the given mythical character can be purchased in v. Hoshiv or in v. Syhota (modern town of Marmarosh-Syhit in Romania) [2, p. 73-74; 30, p. 3; 4 , p. $2 ; 26$, p. 5]. Traditionally the demon-enricher was bought in «flishtzi» (bottle), which had to be brought home and after that be kept under the left arm for nine days. (v. Roztoky) [4, p. 2]. At the beginning of the previous century buying-selling of goblin-servant deal was sealed by blood signature of the person whom the goblin was supposed to serve (v. Zelena) [2, p. 74]. The new host could only buy the devil-enricher on condition that he was not afraid of it and rejected the God (v. Holovy) [3, p. 256].

According to the Hutzul believes, spirit-enricher could be brought up in domestic conditions. For this, one had to take a znosok (the last and smallest egg laid by a hen/an egg without a yolk or with two yolks) and keep it under the left shoulder for nine days (v. Zelena) [2, p. 74-76]. In village Holovy for raising a devil they used the first egg laid by a black hen «squeaker» [4, p. 254; 28, p. 252]. Another way to raise a spirit-enricher was to use an egg laid by a hen on Annunciation, but in this case the hideout could be very angry and fierce [2. p.76; 10, p.113; 12, p. 29]. During the process of raising domestic servant one must not eat, drink, speak or mention the God [4, p. 254]. According to N. Levkovych, the prohibition to pray and cross oneself are caused by the influence of Christianity and virtually mean rejecting the God. Ritual silence and «blindness» correlate the person who wishes to have the spirit-enricher, with the world of the dead [19, p. 118]. The egg had to be put only on the shoulder (t. Vyzhnytzia) $[4$, p. 158]. However, in v. Zelene to raise a domestic servant one had to keep under the arm a black hen, until it lays an egg. Afterwards the hen had to hatch a domestic devil. [26, ark. 4]. It should be pointed out that at the beginning of the previous century Boikos hatched «antypka» (hideout) out of the egg, which necessarily had to be rubbed with ashes of a corpse's bone. This egg was swathed with a damp canvas and kept under the arm until Atypko hatched [31, p. 192; 8, p. 219]. According to traditional Hutzul imagination during the first appearance of the goblin-nurse child he had to be ordered of what he was supposed to take care: farm animals, money or marry girls (v. Zarichchia; v. Holovy) [32, ark. 2; 19, p. 118]. In Check folk mythology the prototype of Hutzul spirit-enricher is mythical character named «shotka» which also was born out of an egg [17, p. 95]. According to the Russian Ethnologist E Levkievska, the ritual of brining the spirit-enricher out of an egg is a way of calling the dark dead from the underworld, which also shows the connection of this mythical character with a genus' ancestors [33, p. 207-208]. Meanwhile in village Zhabie «inclusa» could be raised with the help of magic ritual with money. To realize it, some coins had to be put in a shoe under the left heel on Monday. Then you had to follow a certain routine: not to wash for nine days, not to eat salt; not to speak, not to prey; not to cut nails [7, p. 213-214]. On the Hutzul territory of Bukovyna there existed a ritual of calling the spirit-enricher with the help of verbal-occasional actions on the crossroads. In particular, with the aim to enter selling-guardian relationship with the dark one had to go to a place where a few roads join and whistle three times at midnight. It should be noted that these actions correlate with transcendental properties of crossroads and also mythological Hutzul imagination about devil's settlement at a junction after he was exiled from the heaven [10, p.113]. During the first appearance of domestic servant a demon and a host used to make a «minu» (deal), according to which the spirit-enricher was obliged to his master until his death and after that the former master had to serve his hideout (smt. Verkhovyna; v. Chorni 0slavy) [7; p. 213-214; 34, ark. 7].

A spirit enricher can be received in following situations: 1) subconsciously, a person who sells anything to somebody else had to say «I give with everything» [27, ark. 5]; 2) consciously when a person knows the magical subtext of the verbal phrase «with everything» and on purpose is looking for the aware sellers, wanting to get a welfare and for- 
tune with the help of the dark magic; 3 ) consciously or accidently, when the master of the domestic servant was dying and gave somebody some things «with everything» meaning the spirit-enricher [35, ark. 100]. Thus, a very common way of acquiring a domestic guardian is purchasing it with an actual thing. Ukrainian researcher M. Krasykov focuses on magical objectivity, which takes place in the process of buying a cow. Thus in the Hutzul territory the seller also has to give away its naligachem (a rope or a belt tied to the cow's horns; «kurmyk» in v. Holovy; «loop» in v. Zamahora), meaning that he gives away with milk and everything. But some householders selling their cow do not give away their nalygach, being afraid they will not have any milk from the next cow or that they might give away their luck. In other words, lose their spirit-enricher $[37$, p. 30].

The fact that a goblin is multifunctional testifies about its syncretic properties of the spirit-guardian and the spirit-enricher, as they both can help to look after a cow, in legal cases and making more money (v. Iasenia) [2, p. 74 ]. The person, who has a goblin, is undefeatable in fights, is talented at music or shooting during hunting (v. Holovy) [3, p. 254]. Along with this peculiar feature of Hutzul domestic spirits as well as correlating spirits in the whole Carpathian region, is their narrow specialization, since one goblin is functionally limited only to one kind of actions [20, p. 50]. According to Hutzul mythological believes a host can own a few «hideouts» one of which takes care of horses and cattle, the second one - a house and household, and the third - beehives (t. Kolomyia; Vorohta; v. Chorna Tysa) [4, p. 162; 37, ark. 7; 38, ark. 2]. In Hutzuls' imagination a goblin is able to do all the housework. In particular, in Bukovyna there is a saying that a devil rocks the baby of a rich man: «for the rich man the devil rocks a baby free of charge and for the poor won't even for money» [39, p. 156]. But the main function of the «incluse» is to multiply money for his owner [15, p. 113]. In his turn, the person, who has a hideout is called «Verhobliud» in the researched terrains [7, p. 213-214]. Hutzuls believe that if the goblin is ordered for money, its owner will do well and in five years' time will become very rich $[2$, p. 74]. As they say about a rich person: «He has a boy, the boy helps....» (v. Semakova, Putylskyi district) [28, p. 253].

Having more guardian functions, domestic servants preserve ability to bring damage in case of disrespectful treatment [2, p. 75]. Referring to this V. Halaishuk noted that the goblin is embodiment of a dead ancestor and in its nature is neither evil nor good. It simply exists, having the same right as any family member with a rather high status. Guardian functions are fulfilled only when the so called "codex of conditions» is accomplished or at least not violated [16, p. 123]. Moreover, in the Hutzul territory there is a belief that the hideout does not like salt because according to the overall Ukrainian imagination salt has apotropic properties [40, p. 144; 41, p. 444]. Thus, in village Zelene of Verkhovyna district we manage to find a story that a domestic servant got salty food and his revenge for the master was a disease [26, арк. 5]. Information that the hideout is afraid of salt is written in v. Luhy [28, p. 252].

This certain mythological character (in hutzuls' imagination) has human features and needs. That's why it has to be fed a few times a day. A domestic servant eats milk, sour cream, corn flour, kuleshu, has its own spoon, bowl and a cup [26, p. 4; 4, p. $162 ; 2$, p. 74]. If the hideout is well fed, it sits quietly and if hungry it "roars" and «throws» (v. Holovy; v. Zelena;) [28, p. 252; 2, p. 82; 26, ark. 5]. A hideout as well as a human smokes a pipe (v. Roztoky) [4, p. 13]. The place where the domestic servant resides is the attic or the fireplace ( $v$. Zalena) [26, p. 4; 3, p. 15].

The spirit-enricher («domestic devil») for its service takes away the soul of its owner after his death [25, p. 57]. A difficult death of a person is explained by it as the devil does not allow to die: «because they have a deal that when the master will be dying the hideout will be torturing and excruciating him». When the domestic devil becomes the master of the soul, it takes the soul right to the hell $[2$, p. 76]. Hutzuls believe that in order to avoid a difficult death the host has to give over the hideout to someone else in the family before the death, otherwise the spirit-enricher does not let him die (v. Zelene; v. Middle Bereziv; v. Zarichchia; v. Chorna Tysa) [26, ark, 5; 30, ark. 3; 42, ark. 8; 38, ark. 2]. To give over the "domestic devil" to another owner, the dying person has to whisper: «and take it with yourself» (v. Zarichchia) [42, ark. 9]. In general, according to ethnographical materials, written in the Hutzul territory, domestic servant stays to reside in the house after the master's death [2, p. 82]. There is only one way to get rid of the hideout and it is to hit it with beech in the left hand. And it has to be killed with one strike or else it will stay in the house (v. Holovy) [28, p. 252]. It should be pointed out that the mentioned antidemonical actions are related to Hutzul domestic spirit with the dark dead, namely with a vampire, which also had to be hit with the left hand swingly [5, p. 315]. 
Domestic servant as well as other characters of lower Hutzul mythology has features of anthropomorphism. Some Hutzuls imagine a hideout as a boy (v. Holovy; v. Iasenia) a boy with horns (v. Roztoky), a boy with horse's hoofs and horns ( $v$. Luhy Rakhivskyi district) [До T15, 244; с. 6 3нт2.1; Levk. 252]. In general, it is short and wears boots ( $v$. Roztoky) [v. 13 Znadoby T2].

A separate species of domestic spirit in Hutzul lower mythology is a goblin-animal. According to Hutzul believes domestic spirit-enricher has skills of metamorphosis, so along with anthropomorphic features it can look like a cat (v. Roztoky, v. Zelena, Seredniy Bereziv v. Holovy), a dog (v. Holovy), mouse, fly (v. Zelena), sheep (v. Zelena), frog (t. Vyzhnytsia) $[3$, p. $255 ; 4$, p. $13 ; 30$, p. $2 ; 28$, p. 252 ; 2 , c. $74 ; 4$, p. 14 ; c. 4, p. 158]. Peculiarly, one of the most spread embodiment of goblin animal, is a weasel. Among hutzuls the prohibition to kill this animal is preserved, as the cattle might die (v. Luhy), or luck might disappear (v. Zelene) [28, p. 253]. At the same time if you treat the animal respectfully, then the cattle will do well in the household [2, p. 22]. Hutzuls believe that on the Vlasia holiday one must not do anything for the weasel not to hurt farm animals (v. Kosivska Poliana) [22, ark. 4]. On this day the residents of Kryvorivnia honour the weasel in the following way: they give somebody three eggs for its health, as they consider that a healthy weasel does not hurt anything and a sick one can bit cattle [36, p. 35].

Along with the weasel Hutzul goblin can look like a snake or an eel [3, p. 255]. In the ethnographical descriptions by $F$. Kindle the prohibition to kill snakes is written, as death: «of a snake will lead to the death of a mother» [10, p. 141]. However, from the S. Vytvytzkyi's descriptions we learn that Hutzuls treat snakes respectfully. This snake is called «Sophia». It should be pointed out that «Sophia» origins form ancient Greek «sofos, sopientia», which means skills, knowledge and symbolizes eternity [1, p. 39]. In Zelena village there is a story that the snake, which had been hit, hurt fifty sheep and goats [2, p. 29]. Also Hutzuls believe that they are weasels and snakes that have been sent by witches, who hurt the cattle. (v. Serhii) [10, p. 205]. In some Hutzul territories pientate treatment to domestic snake is still preserved. Particularly, in Holovy village according to respondents, domestic eel lives in the stable and needs to be fed on milk. Domestic eel as well as other zoomorphic embodiments of the goblin, is capable of taking away a cow's milk. As well as in the case of a weasel and a snake, there is a prohibition to kill an eel, otherwise: «a cow can fall down» (get sick) (v. Luhy; v. Velukyi Bychkiv) [28, p. $253 ; 43$, ark. 6]. Positive traits of the goblin-snake can be demonstrated by imitational magic - a way to fight off a hail cloud with the help of a stick, which previously touched a snake. In Hutzul imagination the stick with which people chased away a snake is «very helpful: it can disperse clouds» (v. Zelene; v. Barvinkove) [2, p. 32; 7 p. 221-222]. Imitational magical capability of such stick to influence hail is discovered in v. Kryvorichchia: «the woman chased away a frog and a snake and with the same stick she did so with hail». «An eel with a frog have to be disconnected and with the same stick one can chase away hail. But they both must stay alive and when the hail appears form behind the mountain it will return" (v. Berezhnytzia Verkhovynskyi district) [26, p. 30]. At the same time a stick with which a snake was chased away, can be favourable in legal cases and cure a cow [2, p. 33]. In traditional Hutzul believes a snake's skin and sting also have supernatural properties. To name a few: it can help to cure sheep, keep cow's milk safe and numbs tooth pain (t. Putyla; v. Velykyi Bychkiv) [44, ark. 3; 43, ark. 6]. Moreover, if a snake's sting is attached to a cow's horn, no one can take away its milk. However after this protective ritual the milk can not be given «za prostybi» because it will not be accepted in the underworld. According to Hutzul folk wisdom a snake's sting is good for the blade sharpening and hunting (v. Zelene; v. Kostylivka) [2, p. 32; 45, ark. 2].

It should be emphasized that a snake and an eel are chtonic residents of the underground kingdom, which is considered to be one of the potential places of underworld where the dead ancestors reside. That's why imaginations about the domestic weasel and a snake are peculiar for the Hutzul lower mythology. This also explains their direct connection to the household and their guardian functions over the cattle. Believes about domestic spirit-guardian in the image of a weasel or snake is characteristic for people in Polissia and Boykivshchyna, where the given mythological characters act as protectors of the cattle [20, p. 40;33, p. 117]. Believes in snake and eels as embodiment of the domestic spirit-guardian can also be found in Serbian, Bulgarian, Polish, Check, Lithuanian cultures and connected with manistical totemic motives [46, p. 91-100; 47, p. $159-160 ; 20$, p. $41 ; 48$, p. $193 ; 49$, p. $83 ; 50$, p. 12-14].

Conclusions and further research perspectives. Thus, imaginations about goblin-ancestor («spirit-guardian»), goblin-nurse child («spirit-enricher») and goblin-animal are peculiar for the Hut- 
zul lower mythology. In general, all three types of domestic spirits are related to demonical creatures but differ in their genesis, functional abilities, external visual and domestic every day characteristics. If the spirit guardian has clearly monistic genesis and is created in the result of transitional burial ritual over the genus' ancestor, then the spirit-enricher is connected with certain customary imitational acts (purchase, hatching out of an abnormal egg, coin, inheritance etc). referring to functions the goblin-ancestor is limited to only guardian qualities while the goblin nurse-child has a wider range of various skills (guardianship over the domestic household, providing monetary welfare, giving a talent). However, zoomorphic hypostasis of domestic spirits (weasel, snake, eel), are closely connected with household and are guardians of the cattle. They are also connected with the dark dead as they can imitationally influence the atmospheric phenomena. But some certain characters are left out of the research, thus this issue needs further exploration.

\section{Джерела та література}

1. Витвицький С. Історичний нарис про гуцулів / Софрон Витвицький. - Коломия: Світ, 1993. - 94 с.

2. Онищук А. Матеріали до гуцульської демонології. Записав у с. Зеленици Надвірнянського повіту 1907-1908 pp. / А. Онищук / Матеріали до української етнольогії. - 1909. - Т. ХІ. - С. 1-139.

3. Гнатюк В. Знадоби до галицько-руської демонології / В. Гнатюк // Етнографічний збірник НTШ. - Т. XV. - Львів, 1904. - 272 C.

4. Гнатюк В. Знадоби до української демонології. - Т. II. - Вип. 1 // Етнографічний збірник НTШ - Т. XXXIII. Львів, 1912. - 237 с.

5. Гнатюк В. Похоронні звичаї й обряди / Володимир Гнатюк // Етнографічний збірник НТШ. - Львів, 1912. - Т. XXXI-XXXII. - C. 231-302.

6. Шухевич В. Гуцульщина. Ч. 3 / Володимир Шухевич // Матеріали до українсько-руської етнології. - Львів, 1902. - T. V. - C. 241-255.

7. Шухевич В. Гуцульщина. Ч. 5 / Володимир Шухевич // 3 «Загальної Друкарні». - Львів, 1908. - С. $221-222$.

8. Франко І. Людові вірування на Підгір'ю / І. Франко // Етнографічний збірник НТШ. - Т. V. - Львів, 1898. - С. $160-220$.

9. Шекерик-Доників П. Рік у віруваннях гуцулів / П. Шекерик-Доників. - Верховина, 2009. - 351 с.

10. Кайндль Ф. Р. Гуцули: їх життя, звичаї та народні перекази / Раймунд Фрідріх Кайндль. - Чернівці: Молодий буковинець, 2001. - 208 с.

11. Kolberg 0. Dzieła wszystkie / Oskar Kolberg. - Wrocław-Poznań: PTL, 1970.

- T. 54: Ruś Karpacka: Obraz etnograficzny. Cz. I. - S. 322-334.

12. Wajgiel L. 0 Huculach. Zarys etnograficzny / L. Wajgiel. - Kraków, 1887.

13. Поріцька 0. А. Українська народна демонологія у загальнослов'янському контексті (XIX - поч. XX ст.) / Поріцька 0. А. - К.: Ін-т мистецтвознавства, фольклористики та етнології ім. М.Т. Рильського, 2004. - 180 с.

14. Чеховський І. Г. Демонологічні вірування і народний календар українців Карпатського регіону / Чеховський І.Г. - Чернівці: Зелена Буковина, 2001. - 303 с.

15. Хобзей Н. Гуцульська міфологія: етнолінгвістичний словник / Хобзей Н. - Львів: Ін-т українознавства ім. I. Крип'якевича НАНУ, 2002. - 216 с.

16. Буйських Ю. Домовик у традиційних віруваннях українців: походження образу / Ю. Буйських // Етнічна історія народів Європи. - 2008. - Вип. 26. - С. 120 - 127.

17. Галайчук В. Традиційні уявлення про домашніх духів: українсько-чеські паралелі / В. Галайчук // Проблеми слов'янознавства. 2015. Випуск 64. С. 93-103.

18. Галайчук В. Традиційні уявлення про домашніх духів на Покутті (на матеріалах Городенківського р-ну Івано-Франківської обл.) / В. Галайчук // Народознавчі зошити. № 2 (134), 2017. - С. 341-354.

19. Левкович Н. Демонологічні вірування українців про домашнього духа-опікуна (на сучасних польових матеріалах Бойківщини та Західного Полісся) / Н. Левкович // Фольклористичні зошити Вип. 11. - 2008. - С. $113-121$.

20. Войтович, Н. М. Народна демонологія Бойківщини: монографія / Надія Войтович. - Л.: СПОЛОМ, 2015. - 228 с.

21. Байбурин А.К. Жилище в обрядах и представлениях восточных славян / Байбурин А. К. - Л.: Наука, 1983. $191 \mathrm{c}$.

22. Свідчення респондента Тафійчук Анни, жителя с. Косівська Поляна Рахівського району, Закарпатської області, 1950 року народження, освіта середня, пенсіонер. Записано Іванчуком В.П. 16.04.2018 р. - 4 арк.

23. Urbañczyk S. Religia pogañskich slowian / S. Urbañczyk. - Kraków, 1947. - 152 s.

24. Власова М. Новая Абевега руських суеверий: Иллюстированный словарь / М. Власова. СПб., 1995.

25. Галайчук В. Українська міфологія / Володимир Галайчук. - Харків: Клуб Сімейного Дозвілля, 2016. - 288 с.

26. Свідчення респондента Потяк Василини, жительки с. Зелене Верховинського району, Івано-Франківської об- 
ласті, 1961 року народження, освіта середня технічна. Записано Іванчуком В.П. 17.07.2015 р. - 7 арк.

27. Свідчення респондента Кравчук Марії, жительки с. Космач Косівського району, Івано-Франківської області, 1935 року народження, освіта початкова, пенсіонер. Записано Іванчуком В.П. 13.07.2016 p. - 7 арк.

28. Левкиевская Е. Материалы по Карпатской мифологии / Е. Левкивская // Славянский и Балканский фольклор: верования, текст, ритуал. Институт словяноведения и балканістики. - М. - 1994. - С. 251-261.

29. Буйських Ю. Нижча міфологія українців у світлі проблем «двовір'я» та «народного християнства» / Ю. Буйських // Етнічна історія народів Європи. - 2010. - Вип. 33. - С. 70 - 80.

30. Свідчення респондента Куничин Марії, жителя села Середній Березів Косівського району, Івано-Франківської області, 1947 року народження, освіта середня, пенсіонер. Записано Іванчуком В.П. 11.07.2017 р. - 3 арк.

31. Чубинский П. Труды этнографическо-статистической экспедиции в Западно-Русский край: Т 1. / собрал П. Чубинский. - Санкт-Петербург, 1877 - 462 с.

32. Свідчення респондента Клим'юк Парасковії, жителя села Заріччя Надвірнянського району, Івано-Франківської області, 1931 року народження, освіта початкова, пенсіонер. Записано Іванчуком В.П. 10.07.2017 р. - 6 арк.

33. Левкиевская Е. Е. Славянские представления о способах комуникации между тем и єтим светом / Е. Е. Левкиевская // Концепт движения в языке и культуре. - М., 1996. - С. 185-212.

34. Свідчення респондента Козловської Розалії, жителя села Чорні Ослави Надвірнянського району, Івано-Франківської області, 1933 року народження, освіта початкова, пенсіонер. Записано Іванчуком В.П. 19.06.2017 р. - 7 арк.

35. Буйських Ю. Система традиційних міфологічних вірувань та уявлень гуцулів у вимірі сучасності / Ю. Буйських // Народна творчість та етнологія №1, 2014. - С. 98-107.

36. Красиков. М. Імітативна магія у звичаєвості гуцулів Верховинщини / М. Красиков // Народна творчість та етнологія. № 6/2013. - С. 27-36.

37. Свідчення респондента Никорак Анни, жителя селища міського типу Ворохта, Яремчанської міськради, Івано-Франківської області, 1950 року народження, освіта початкова, пенсіонер. Записано Іванчуком В.П. 08.07.2017 р. -7 арк.

38. Свідчення респондента Бандуряк Тетяни, жителя с. Чорна Тиса Рахівського району, Закарпатської області, 1947 року народження, освіта середня, пенсіонер. Записано Іванчуком В.П. 17.04.2018 р. - 2 арк.

39. Кайндль Ф. Приповідки буковинських Руснаків і Гуцулів / Ф. Кайндль // Етнографічний збірник. - 1898. - Т. V. - C. 156-159.

40. Трумко Дз. Українські традиційні апотропеї та апотропейні дії пов'язані новонародженою дитиною / Дз. Трумко // Наукові зошити. Вип 11., 2010. - С. 141-150.

41. Валенцова М. М. Соль / М. М. Валенцова // Славянская мифология. Энциклопедический словарь. (а-я). [изд. 2-е]. - М.: Международные отношения, 2002. - 628 с.

42. Свідчення респондента Клим'юк Ірини, жительки села Заріччя Надвірнянського району, Івано-Франківської області, 1932 року народження, освіта початкова, пенсіонер. Записано Іванчуком В.П. 28.06.2016 p. - 21 арк.

43. Свідчення респондента Томаш Анни, жителя смт. Великий Бичків Рахівського району, Закарпатської області, 1956 року народження, освіта середня, пенсіонер. Записано Іванчуком В.П. 16.04.2018 р. -5 арк.

44. Свідчення респондента Петращука Володимира, жителя селища міського типу Путила, Чернівецької області, 1956 року народження, освіта середня, пенсіонер. Записано Іванчуком В.П. 02.10.2018 р. - 3 арк.

45. Свідчення респондента Тафійчук Олени Павлівни, жителя с. Костилівка Рахівського району, Закарпатської області, 1950 року народження, освіта вища, пенсіонер. Записано Іванчуком В.П. 17.04.2018 р. - 2 арк.

46. Георгиева И. Бьлгарска народна митологія / И. Георгиева. - София, 1993.

47. Вакарлски Хр. Бьлгарски погребальни обичаи: Сравнително изучаване / Хр. Вакарлски. -София, 1990. - 240 с.

48. Horvathova E. Rok vo zvykoch nasho l’udu / E. Horvathova. - Bratislawa, 1986. - 256 c.

49. Виноградова Л.Н. Народная демонология и мифо-ритуальная традиция славян / Виноградова Л.Н. - М.: Индрик, 2000. $-431 \mathrm{c}$.

50. Колесса Ф. Вірування про душу й загробне життя в українській похоронній і поминальній обрядності / Ф. Колесса // ЗНТШ. - Т. CCXLII. Праці Секції етнографії та фольклористики. - Львів, 2001. - С. 7-82. 